\title{
TERT Copy Number Alterations, Promoter Mutations and Rearrangements in Adrenocortical Carcinomas
}

\author{
Sounak Gupta ${ }^{1,5} \cdot$ Helen Won ${ }^{1} \cdot$ Kalyani Chadalavada $^{2} \cdot$ Gouri J. Nanjangud $^{2} \cdot$ Ying-Bei Chen ${ }^{1}$. \\ Hikmat A. Al-Ahmadie ${ }^{1}$. Samson W. Fine ${ }^{1}$. Sahussapont J. Sirintrapun ${ }^{1} \cdot$ Vivian E. Strong $^{3} \cdot$ Nitya Raj $^{4}$. \\ Diane Reidy Lagunes ${ }^{4}$. Chad M. Vanderbilt ${ }^{1}$. Michael F. Berger ${ }^{1} \cdot$ Marc Ladanyi $^{1}$. Snjezana Dogan ${ }^{1}$. \\ Satish K. Tickoo ${ }^{1}$. Victor E. Reuter ${ }^{1}$. Anuradha Gopalan ${ }^{1}$
}

Accepted: 30 August 2021 / Published online: 22 September 2021

(c) The Author(s) 2021

\begin{abstract}
Molecular characterization of adrenocortical carcinomas (ACC) by The Cancer Genome Atlas (TCGA) has highlighted a high prevalence of TERT alterations, which are associated with disease progression. Herein, 78 ACC were profiled using a combination of next generation sequencing $(n=76)$ and FISH $(n=9)$ to assess for TERT alterations. This data was combined with TCGA dataset $(n=91)$. A subset of borderline adrenocortical tumors $(n=5)$ and adrenocortical adenomas $(n=7)$ were also evaluated. The most common alteration involving the TERT gene involved gains/amplifications, seen in 22.2\% (37/167) of cases. In contrast, "hotspot" promoter mutations ( $\mathrm{C}>\mathrm{T}$ promoter mutation at position -124, 7/167 cases, 4.2\%) and promoter rearrangements $(2 / 165,1.2 \%)$ were rare. Recurrent co-alterations included $22 \mathrm{q}$ copy number losses seen in $24 \%$ (9/38) of cases. Although no significant differences were identified in cases with and without TERT alterations pertaining to age at presentation, tumor size, weight, laterality, mitotic index and Ki67 labeling, cases with TERT alterations showed worse outcomes. Metastatic behavior was seen in 70\% (28/40) of cases with TERT alterations compared to 51.2\% (65/127, $p=0.04$ ) of cases that lacked these alterations. Two (of 5) borderline tumors showed amplifications and no TERT alterations were identified in 7 adenomas. In the borderline group, 0 (of 4) patients with available follow up had adverse outcomes. We found that TERT alterations in ACC predominantly involve gene amplifications, with a smaller subset harboring "hotspot" promoter mutations and rearrangements, and 70\% of TERT-altered tumors are associated with metastases. Prospective studies are needed to validate the prognostic impact of these findings.
\end{abstract}

Keywords TERT . Adrenocortical carcinoma $\cdot$ Adrenocortical adenoma $\cdot$ TCGA

Anuradha Gopalan

gopalanA@mskcc.org

1 Department of Pathology, Memorial Sloan Kettering Cancer Center, 1275 York Avenue, New York, NY 10065, USA

2 Molecular Cytogenetics Core Facility, Memorial Sloan Kettering Cancer Center, New York, NY, USA

3 Department of Surgery, Gastric and Mixed Tumor Service, Memorial Sloan Kettering Cancer Center, New York, NY, USA

4 Division of Solid Tumor Oncology, Department of Medicine, Memorial Sloan Kettering Cancer Center, New York, NY, USA

5 Present Address: Mayo Clinic, Rochester, MN, USA

\section{Introduction}

Programmed loss of telomeric DNA (telomere shortening) in somatic cells leads to the activation of DNA damage responses and subsequent cell cycle arrest and senescence [1]. Telomerase reverse transcriptase, which is encoded by the TERT gene, forms an important component of the telomerase complex and TERT mediated de novo telomeric DNA synthesis in rapidly proliferating cancer cells prevents chromosomal ends from being recognized as sites of DNA damage [1]. This prevents the initiation of repair pathways and allows neoplastic cells to escape telomere crisis [1]. Alterations of the TERT gene such as "hotspot" promoter mutations, amplifications and promoter rearrangements have been associated with increased TERT expression and these 
alterations have been frequently seen in multiple cancer types [2-6].

Adrenocortical carcinomas are rare endocrine malignancies with an estimated annual incidence of 0.7 to 2 per million and advanced stage neoplasms are associated with extremely poor outcomes [7-12]. Whole genome doubling associated with decreased telomere length and increased TERT expression has been associated with disease progression in adrenocortical carcinomas in The Cancer Genome Atlas (TCGA) datasets [12]. A high incidence of genomic amplifications at the TERT locus (5p15.33) has also been identified in at least two separate studies (TCGA $\approx 15 \%, 13$ of 89 ; Assie et al. $\approx 6 \%, 7$ of 122) [12, 13]. In comparison, "hotspot" TERT promoter alterations are relatively rare in this tumor type along with TERT promoter rearrangements, and the latter are poorly characterized and under-recognized $[3,4,12,13]$. Due to an association between whole genome doubling and TERT expression in a prior TCGA study, it has been suggested that TERT is required in a subset of adrenocortical carcinomas for telomere maintenance [12].

As there is a paucity of prognostic biomarkers in adrenocortical carcinomas, we interrogated a large cohort of 169 cases (institutional cohort: 78, TCGA: 91) for TERT alterations and correlated the presence of these alterations with various clinicopathologic parameters and outcomes.

\section{Materials and Methods}

\section{Patient Specimens}

This study was approved by our Institutional Review Board. Adrenocortical carcinomas were diagnosed using modified Weiss criteria and some of the features of malignant tumors are illustrated in Fig. 1. In addition, the Lin-WeissBisceglia system was used for oncocytic adrenocortical tumors [14-18]. Tumors with a score of 3 under the Weiss system, and those fulfilling 1 to 4 minor criteria under the Lin-Weiss-Bisceglia system were classified as "borderline" in this study. Eighty-seven adrenocortical neoplasia (76 adrenocortical carcinomas, 4 adrenocortical borderline tumors and 7 adrenocortical adenomas) were analyzed by a next generation sequencing (NGS)-based assay, Memorial Sloan Kettering Cancer Center Integrated Mutation Profiling of Actionable Cancer Targets (MSK-IMPACT), as part of an institutional clinical cancer genomics initiative [5, 19, 20]. A subset of 9 adrenocortical carcinomas and 1 borderline adrenocortical tumor were analyzed using fluorescence in situ hybridization (FISH). Cases profiled by FISH included 3 cases that were only profiled using this testing modality (adrenocortical carcinoma: 2; adrenocortical borderline tumor: 1). Archived $\mathrm{H} \& \mathrm{E}$ and immunohistochemical-stained slides were reviewed and medical records were accessed for relevant clinicopathologic features including outcomes on follow up.

\section{Next Generation Sequencing-Based Molecular Profiling}

Specifics regarding the MSK-IMPACT assay have been previously reported $[5,19,20]$. This assay involves hybridization capture-based library preparation followed by deep sequencing of select noncoding regions and 6614 proteincoding exons of 468 genes (previous versions interrogated 341 and 410 genes) including TERT [6]. Sequencing 500 bases upstream of the TERT promoter allows for the identification of "hotspot" promoter mutations as well as structural variants that may occur in this region [6]. In addition, the homogenous distribution of single nucleotide polymorphism tiling probes across the genome allows for assessment of copy number alterations. Based on previously reported criteria, gains were defined as a fold change $\geq 1.5$ and $<2.0$, while amplifications were defined as a fold change $\geq 2.0$ [21-23].

\section{Fluorescence In Situ Hybridization}

Fluorescence in situ hybridization (FISH) analysis was performed on paraffin sections using a 3-color probe set. The probe mix consisted of BAC clones spanning the TERT gene (5p15), while probes for the $5 \mathrm{p} 12$ and $5 \mathrm{q} 11$ loci served as controls. Probe labeling, tissue processing, hybridization, post-hybridization washing, and fluorescence detection were performed according to standard laboratory procedures. Slides were scanned using a Zeiss Axioplan 2i epifluorescence microscope equipped with MetaSystems (Waltham, MA) imaging system. Metafer and VSlide modules within the system were used to generate virtual image of H\&E and DAPI-stained sections. For all cases, the corresponding H\&E sections assisted in localizing regions of interest for downstream analysis. Signal counts were performed on a minimum of 20 discrete nuclei and only nuclei with at least 2 signals for $T E R T$ and control probes were selected. TERT amplification was defined as $\geq 10$ copies of TERT or a TERT: $5 \mathrm{q} 11$ probe ratio $>2$. Cells with large clusters of TERT signal (high-level HSR type amplification), were interpreted as being amplified.

\section{Literature Review and Data Extraction from the Cancer Genome Atlas Datasets}

The publicly available cBioPortal.32e34 platform was used to analyze data from The Cancer Genome Atlas (TCGA) pertaining to pan-genomic characterization of adrenocortical carcinomas [24, 25]. 

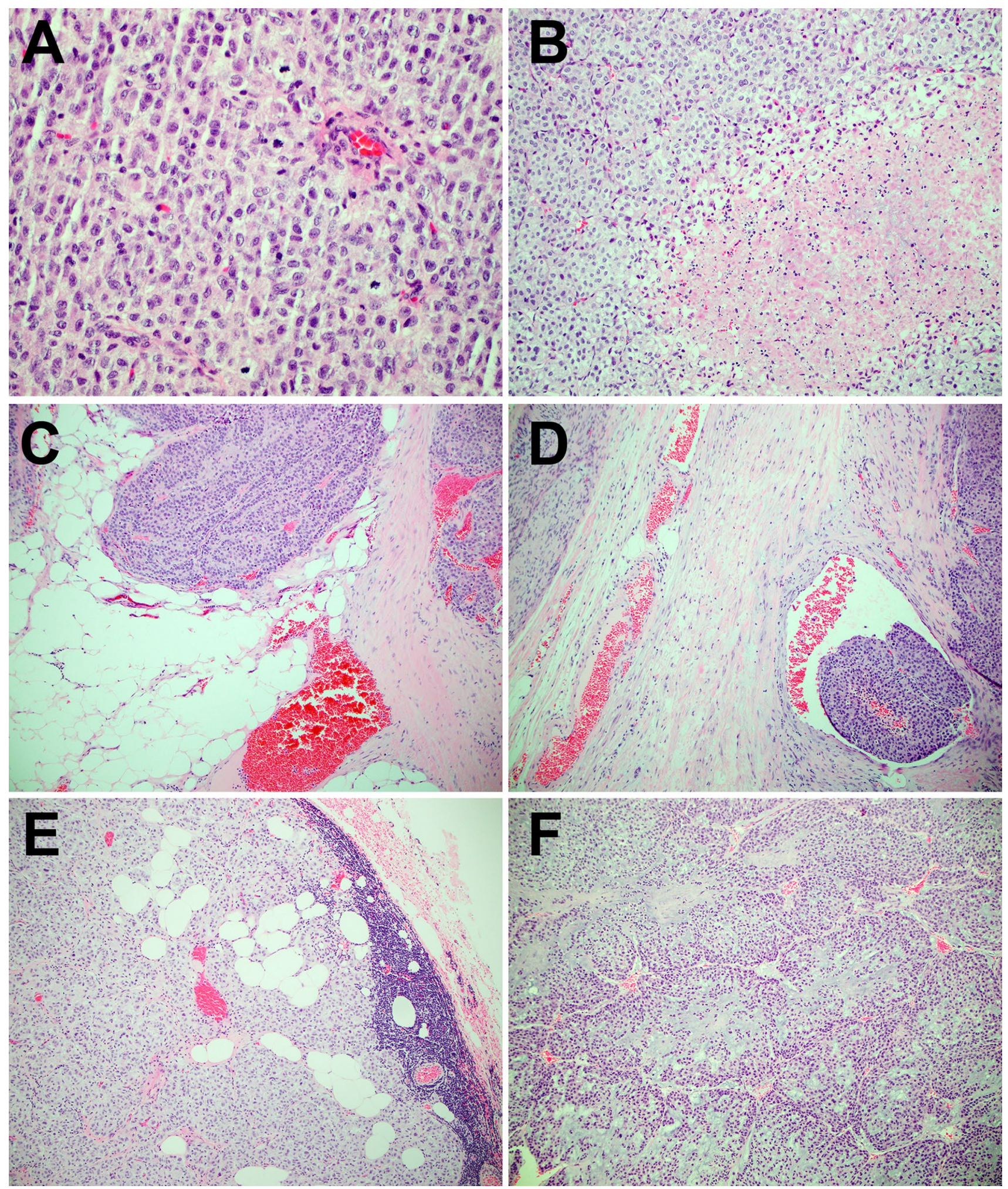

Fig. 1 Histopathologic features of adrenocortical carcinomas including high mitotic index (a), necrosis (b), extra-capsular extension (c), been depicted. An adrenocortical carcinoma with myxoid features (f) lymphovascular invasion (d), and lymph node involvement (e) have that harbored a TERT amplification has been shown 


\section{Statistical Analysis}

Continuous variables were evaluated with frequency counts and percentages and all tests to assess for statistical significance were two-sided and $p$-values $<0.05$ were considered significant.

\section{Results}

\section{Prevalence of TERT Alterations in Adrenal Cortical Carcinomas}

76 adrenocortical carcinomas were evaluated for "hotspot" TERT promoter mutations as well as for structural variants involving the first 500 bases upstream of the transcriptional start site (Table 1). In addition, using a combination of NGS $(n=76)$ and FISH $(n=9), 78$ cases of adrenocortical carcinomas were evaluated for copy number alterations (Table 1 ).

The most common alteration involving the TERT gene involved genomic gains/amplifications which were seen in $30.7 \%$ of cases (24/78; Fig. 2A-B; Table 1). After taking into consideration similar events identified in TCGA datasets, the combined incidence for gains/amplifications was $22.2 \%$ (37 of 167 cases) [25]. This was significantly higher compared to both TERT promoter rearrangements $(2 / 165$, $1.2 \%$ cases; Fig. $2 \mathrm{C}$; Table 1) and "hotspot" $\mathrm{C}>\mathrm{T}$ promoter mutations at position -124 relative to the transcription start site (also referred to as the C228T alteration, 7/167, 4.2\% cases; Fig. 2D; Table 1) [25]. Interestingly, consistent with a prior TCGA study, no C250T promoter alterations were identified in our institutional dataset [12]. In addition, these TERT alterations (gains/amplifications, "hotspot" promoter mutations and promoter rearrangements) were mutually exclusive events.
Of note, 2 of 5 borderline adrenocortical tumors showed similar TERT gains/amplifications (Table 1), while no TERT alterations were identified for 7 adrenocortical adenomas.

\section{Clinicopathologic Features of Adrenocortical Carcinomas with TERT Alterations}

After evaluating abstracted data from institutional cases $(n=78)$ and TCGA cases $(n=89)$, no significant differences were identified regarding mean age at presentation, tumor laterality, size and weight, irrespective of TERT alteration status (Table 2). Similarly, while cases with TERT alterations tended to have a lower mitotic index and Ki67 labeling (proliferative index), neither of these metrics were statistically significant (Table 3). Interestingly, adrenocortical carcinomas in both the institutional and TCGA cohorts showed a female predilection, irrespective of TERT status and the significance of this observation is unclear (Table 2).

Recurrent alterations that co-occurred with TERT alterations included 22q (NF2/SMARCB1) copy number losses in $24 \%$ of cases ( 9 of 38 ). Furthermore, copy number losses at 9p21 (CDKN2A/CDKN2B) and alterations involving TP53, $C T N N B 1$ and $N F 1$ were each seen in $\leq 16 \%$ of cases with TERT alterations in the institutional and TCGA cases combined $(n=38)$ (Table 3 ).

For patients with at least 3 months of clinical follow up (institutional cohort, $n=48$; TCGA, $n=48$, total, $n=96$ ) the presence of TERT alterations correlated with adverse clinical outcomes. While TCGA data suggested a trend towards worse outcomes $(69.2 \%$ vs $38.2 \%, p=0.06)$, defined as documented metastatic disease either at diagnosis or on follow up, no such statistically significant differences were identified in the institutional cohort of cases $(70.6 \%$ vs $70.4 \%$, Table 2). However, at the same time for all cases combined, those with TERT alterations $(28 / 40,70 \%)$ had worse outcomes compared to those that lacked alterations of

Table 1 Prevalence of TERT alterations in adrenal cortical tumors

\begin{tabular}{|c|c|c|c|c|}
\hline & MSKCC cohort (ACC) & TCGA (ACC) & MSKCC and TCGA (ACC) & $\begin{array}{l}\text { MSKCC } \\
\text { (borderline } \\
\text { tumors) }\end{array}$ \\
\hline Total cases & 78 & 91 & 169 & 5 \\
\hline$T E R T$ alterations $(\%)$ & 27 of $78(34.6 \%)$ & 18 of $91(19.8 \%)$ & 45 of $169(26.6 \%)$ & 2 of $5(40 \%)$ \\
\hline TERT promoter mutations (\%) & 3 of $76(3.9 \%)$ & 4 of $91(4.4 \%)$ & 7 of 167 Cases $(4.2 \%)$ & 0 of $4(0 \%)$ \\
\hline$T E R T$ amplifications (\%) & $24^{\mathrm{a}}$ of $78(30.7 \%)$ & 13 of 89 Cases $(14.6 \%)$ & $37^{\mathrm{a}}$ of 167 Cases $(22.2 \%)$ & 2 of $5(40 \%)$ \\
\hline $\begin{array}{l}T E R T \text { copy number (mean fold change } \\
\text { by MSK-IMPACT) }\end{array}$ & $\begin{array}{l}2.1, \text { range } 1.5 \text { to } 5.8 \\
(n=22)\end{array}$ & - & - & $1.5(n=1)$ \\
\hline Structural variants (TERT promoter) & $1^{\mathrm{a}}$ of $76(1.3 \%)$ & 1 of 89 Cases $(1.1 \%)$ & $2^{\mathrm{a}}$ of 165 Cases $(1.2 \%)$ & 0 Cases \\
\hline
\end{tabular}

No TERT alterations were identified for 7 cases of adrenocortical adenomas which were profiled using MSK-IMPACT (including 3 oncocytic adenomas and 1 pigmented adenoma). MSK-IMPACT copy number predictions for TERT amplification was confirmed by FISH for 8 cases and copy number assessment was performed using FISH only for 2 cases

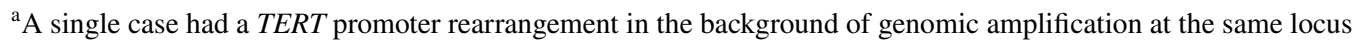



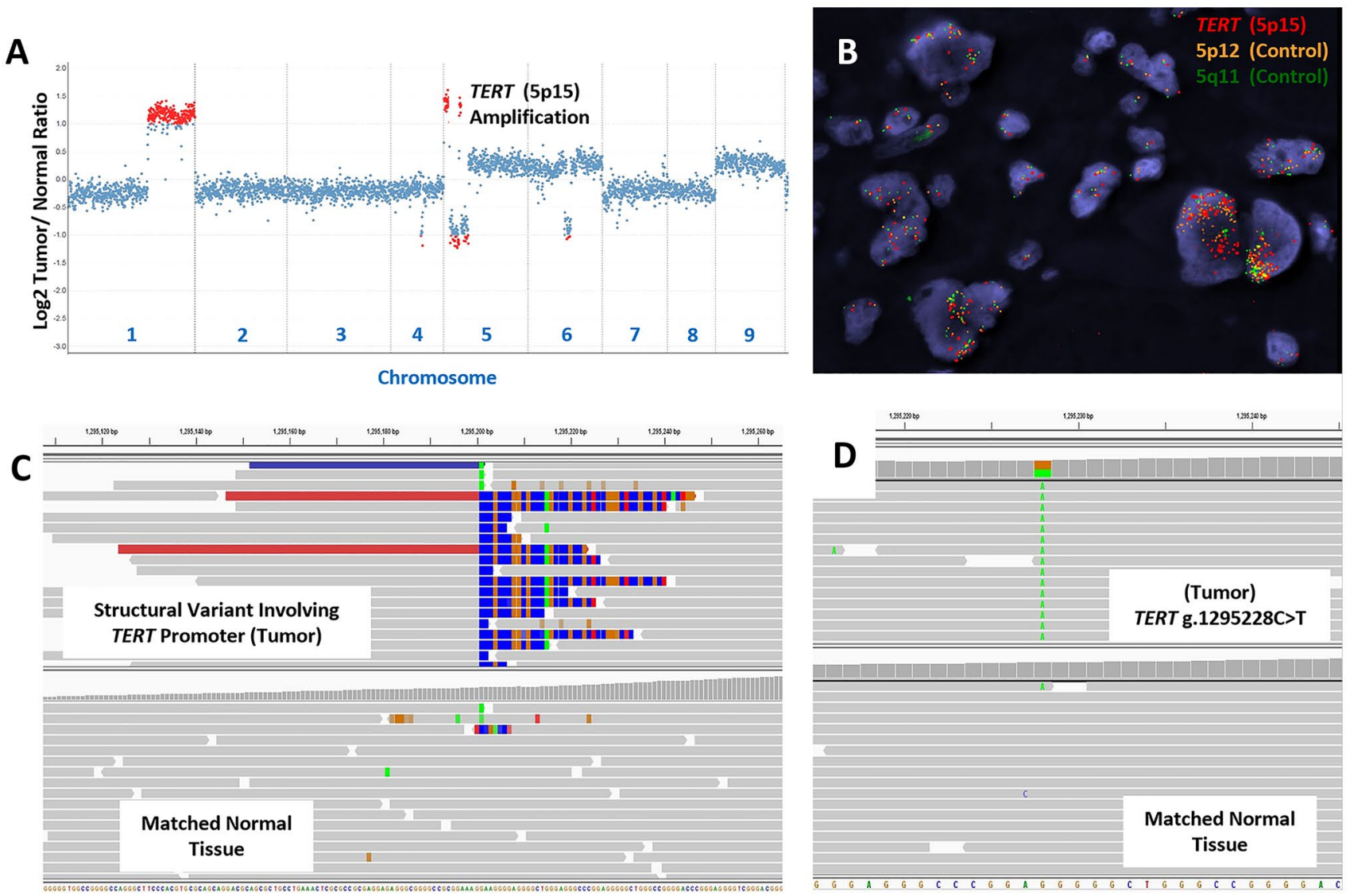

Fig. 2 Copy number alterations for an adrenocortical carcinoma, including TERT amplification, determined using next generation sequencing and fluorescence in situ hybridization has been depicted (a, b). Relative ( $\log 2)$ tumor/normal ratios (y axis) and corresponding chromosomes (x axis) are displayed, with each blue dot representing an individual probe region and amplified regions are shown in red

the TERT gene (65/127, 51.2\%, $p=0.04$; Table 2), including 6/35 (17.1\%) patients with TERT alterations dying of disease related complications compared to $6 / 127$ patients that lacked these alterations $(4.7 \%, p=0.02$; Table 2$)$. These findings suggest that TERT alterations do indeed adversely affect outcomes.

\section{Discussion}

This is a large study involving 181 cases of adrenocortical tumors. A combination of hybrid-capture based next generation sequencing/ fluorescence in situ hybridization $(n=78)$ and whole exome sequencing/targeted TERT promoter sequencing (The Cancer Genome Atlas, $n=91$ ) was used to define both the prevalence of copy number alterations and "hotspot" promoter mutations affecting the TERT gene in adrenocortical carcinomas. Unique findings of this study include understanding the landscape of TERT alterations in (a). Corresponding fluorescence in situ hybridization results using probes for TERT (5p12, red) and control probes (5p12, yellow; $5 \mathrm{q} 11$, green) is shown (b). A structural rearrangement of the TERT promoter region with CLPTMIL (c), and a somatic TERT promoter mutation (g.1295228C > T) (d) identified using hybridization-capture based next generation sequencing has been depicted

these tumors which predominantly include gene amplifications, with a smaller subset harboring "hotspot" promoter mutations and rearrangements. The documentation of an increased incidence of metastatic disease $(70 \%$ vs $51.2 \%$, $p=0.04$ ) and disease specific death (6 of $25,17.1 \%$ vs 6 of $127,4.7 \%$ ) among patients with known TERT alterations in combined institutional/ TCGA cases of adrenocortical carcinomas suggests that these alterations may have significant impact on prognostication. This observation is further underscored by the fact that no TERT alterations were identified in 7 cases of adrenocortical adenomas. While TERT amplifications were identified in 2 of 5 borderline adrenocortical tumors, clinical follow up was available for only one of these patients and the prognostic significance of this finding in borderline tumors is therefore unclear.

The spectrum of alterations that have been shown to increase TERT expression across tumor types are broad [6]. While genomic amplification events for TERT at the 5 p15.33 locus have been documented in multiple studies of 


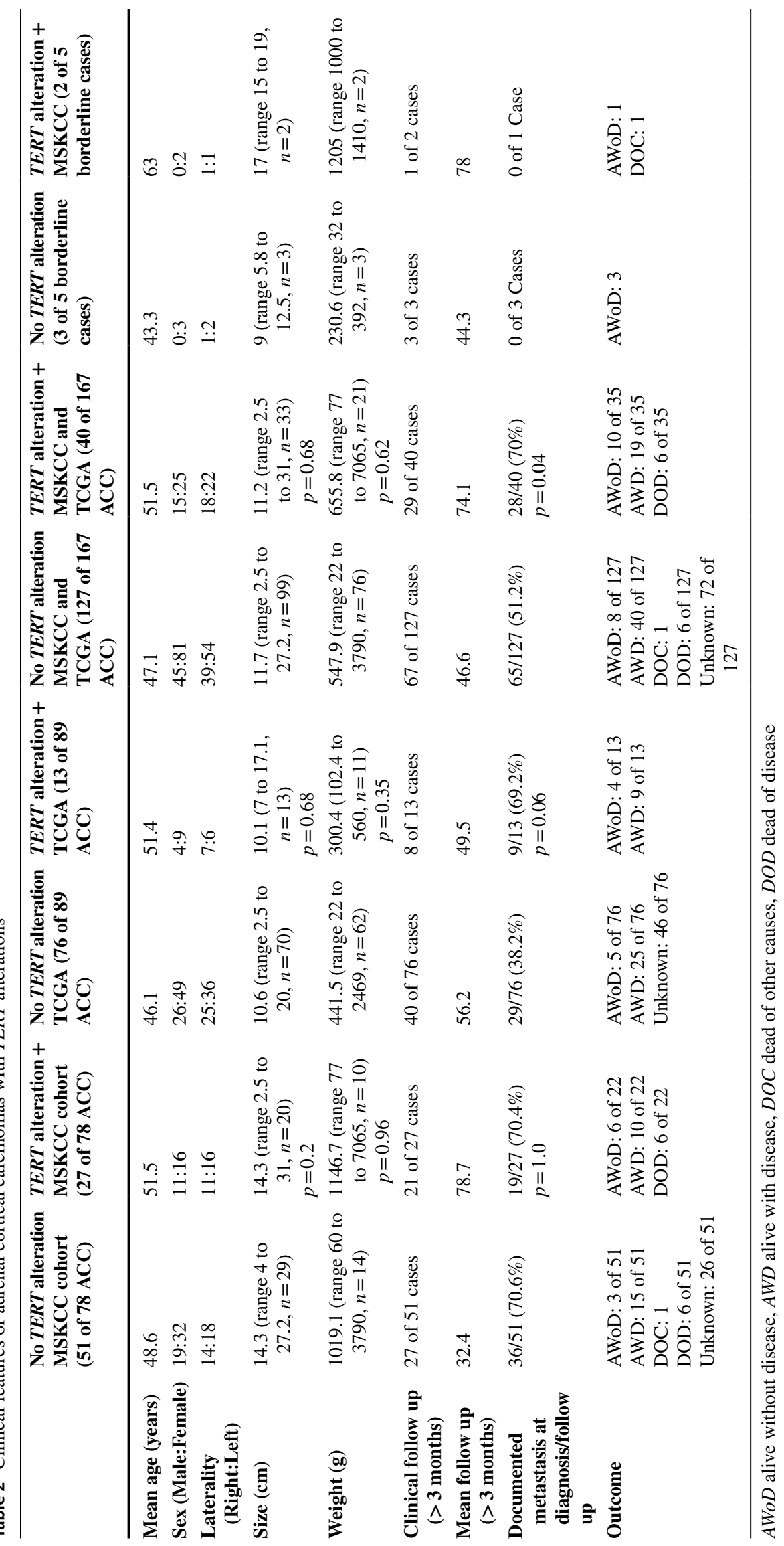




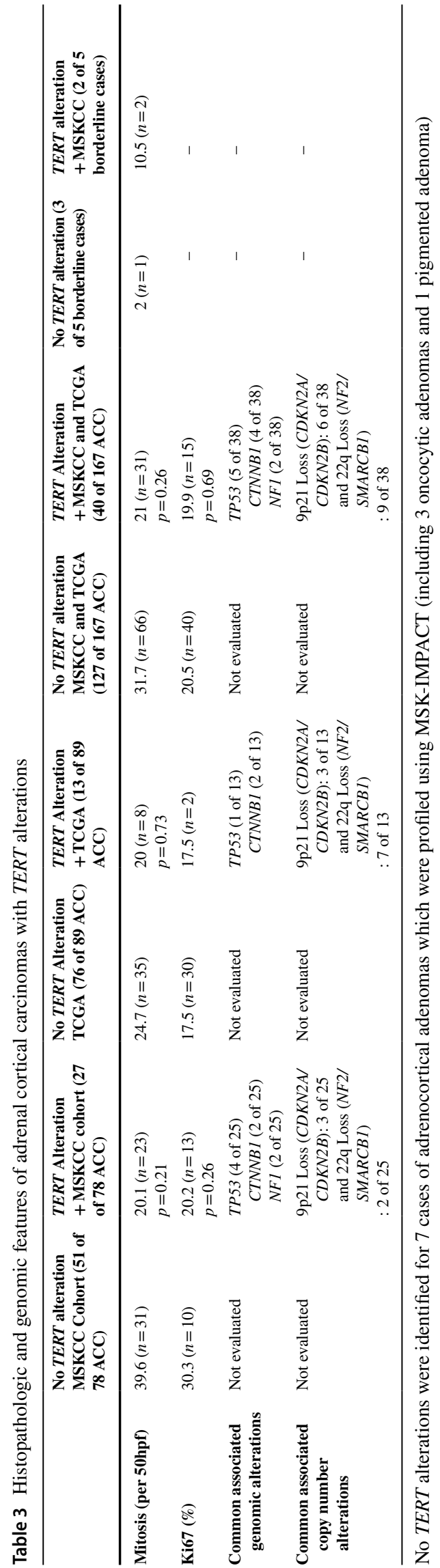

adrenocortical carcinomas, other mechanisms of upregulation of TERT have been documented across various tumor types $[6,12,13,26-30]$. For instance, $\mathrm{G}>\mathrm{A}$ substitutions at -124 and -146 base pairs upstream of the transcription start site for the TERT gene (also referred to as "C228T" and "C250T" promoter mutations) are known to increase recruitment of the heterotetrameric GABP transcription factor complex; this complex binds both at this site and at an adjacent ETS binding site to consequently upregulate TERT gene expression [5, 6, 31-33].

Rearrangement events occurring within the TERT promoter region have been documented in select tumor types and are thought to upregulate TERT expression by juxtaposing the TERT coding sequence to strong enhancer elements $[3,4,6]$. While whole genome sequencing approaches have been successful in identifying such alterations, these events are likely under-recognized as most contemporary next generation sequencing assays only sequence a limited portion of the TERT promoter [3, 6]. For instance, the MSK-IMPACT assay which sequences the first 500 base pairs upstream of the TERT transcription start site was able to identify one such event and in the absence of gene expression data, the functional significance of such alterations remains to be better defined [6]. Only one such case was identified in the cohort of adrenocortical carcinoma profiled by TCGA (TCGA-OR-A5JS) and this case harbored a CCDC47-TERT fusion. Due to the rarity of these events in adrenocortical carcinomas there is insufficient data at present to comment on whether TERT structural variants in this tumor type exhibit a conserved breakpoint.

In addition, hypermethylation of specific $\mathrm{CpG}$ islands upstream of the TERT transcriptional start site have been associated with increased TERT expression and aggressive disease in both pediatric brain tumors and in adrenocortical carcinomas [30, 34]. However, a recent study suggests that these hypermethylation events are not mutually exclusive with other TERT alterations such as promoter mutations and/ or copy number alterations [6].

A prior study of pediatric adrenocortical carcinomas had documented a high incidence of TERT amplifications in a relatively small cohort of patients ( 13 of $19,68.4 \%$ ) without evaluating for "hotspot" promoter mutation status [26]. In the current study, only a minority of adrenocortical carcinomas occurred in patients less than 20 years of age (institutional cohort: 4 of 78 cases; The Cancer Genome Atlas: 3 of 91 cases) and no TERT alterations were documented in these cases.

After combining the results of our study with TERT alterations reported in other studies of adrenocortical carcinomas (Assie et al. 122 cases; Liu et al. 34 cases; Juhlin et al., 41 cases), the overall prevalence of combined amplification $(n=330)$ and "hotspot" promoter mutation events $(n=364)$ 


\title{
Prevalence of TERT Alterations in Adrenocortical Carcinomas
}

\author{
All Cases (Amp: 330 Cases; PM: 364 Cases) \\ Current Study (Amp: 78 Cases, PM: 76 Cases) \\ Zheng et al (TCGA; Amp: 89 Cases, PM: 91 Cases) \\ Liu et al (PM only, 34 Cases)

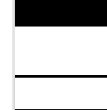 \\ - TERT Amplification \\ Juhlin et al (41 Cases)

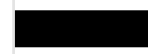 \\ $\square$ TERT Promoter Mutation \\ Assie et al (122 Cases)

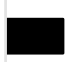

\begin{tabular}{lllll}
\hline 0 & 40 & 60 & 80 & 100 \\
Percentage & 60 & &
\end{tabular}

Fig. 3 The prevalence of TERT alterations (genomic amplifications, black; "hotspot" promoter mutations, white) in the current study, compared to previously reported cases from representative studies in the literature have been shown. The total number of cases that were

was approximately $18.2 \%$ (Fig. 3) [13, 27, 28]. Our results suggest that TERT gains/amplifications (mean $15.2 \%$, range $5.7 \%$ to $30.8 \%$ ) occur more frequently than "hotspot" promoter mutations (mean $3.0 \%$, range 0 to $11.8 \%$ ).

With regards to tumors with divergent histologic features, 3 cases of adrenocortical carcinoma with focal myxoid change were identified in a 45-year-old male, 64-year-old female and a 68-year-old female, respectively. All 3 patients had amplifications of the TERT gene and had metastatic disease at diagnosis or on follow up, and at least 2 patients were dead of cancer-related causes at last follow up. On histopathologic examination, the mitotic count for these cases was: 2, 5 and 56 per 50 high power fields, necrosis was identified in 2 cases, and capsular and/or vascular invasion was identified in all. None of the cases included in our series was a rare histologic variant. Additional studies are needed to address whether TERT alterations are enriched in rarer histologic variants of adrenocortical carcinomas such as the myxoid variant.

Due to the rarity of molecular profiling of adrenocortical carcinomas, data correlating TERT status with clinicopathologic variables and outcomes is limited, with at least 1 study suggesting that whole genome doubling associated with increased TERT expression has been associated with disease progression in adrenocortical carcinomas [12]. Specifically, abstracted data from institutional and TCGA cases were reviewed to identify potential associations between TERT alteration status and clinicopathologic features such as: age at presentation, sex, tumor laterality, size and weight. profiled for amplification events (Amp) and "hotspot" promoter mutations (PM) in each study has been depicted in the figure legend on the left. TCGA The Cancer Genome Atlas

While no significant trend was identified for these variables in association with TERT alterations, a female predilection was identified for combined institutional and TCGA cases (female: 106 of 166 cases, 64\%) and supports what has been reported in the literature [8]. Some parameters that have been used for prognostic stratification of adrenocortical carcinomas include: mitotic frequency and Ki67 labeling index [35-40]. However, no significant association between Ki67 labeling index and mitotic activity and TERT alteration status was identified in combined institutional / TCGA cases in our study. Finally, recurrent molecular alterations identified in cases with TERT alterations included 22q (NF2/ SMARCB1) and 9p21 (CDKN2A/CDKN2B) copy number losses that were identified in $24 \%$ and $16 \%$ of cases, respectively, and the significance of this finding is unclear, as well.

In contrast to molecular analysis for TERT promoter mutation detection which yields a binary result, defining a cutoff for TERT amplification (using either FISH or NGS) is somewhat arbitrary. Based on previously reported criteria, gains were defined as a fold change $\geq 1.5$ and $<2.0$, while amplifications were defined as a fold change $\geq 2.0$ for NGS assays. Regarding FISH: $\geq 10$ copies of TERT, or a TERT: $5 \mathrm{q} 11$ probe ratio $>2$, or large clusters of TERT signal (highlevel HSR type amplification) met criteria for TERT amplification. For 6 cases of adrenocortical carcinomas with TERT gene amplifications profiled using both NGS and FISH, the results of both testing modalities were concordant. It must be noted that in contrast to NGS, FISH has the advantages of being a widely available and cost-effective test, with a 
shorter turnaround time that may be easier to implement into routine clinical practice. However, future studies are needed to further refine both NGS and FISH-based criteria to define amplification in adrenocortical carcinomas.

In summary, the results of our study suggest that TERT alterations occur frequently in adrenocortical carcinomas and not in adrenal adenomas, and that copy number gains/ amplifications are much more frequent compared to "hotspot" promoter mutations. In addition, TERT alterations may be associated with adverse outcomes such as metastatic disease and death from disease. These findings need to be further validated in prospective studies.

Funding The authors of this article have no relevant financial relationships with commercial interests to disclose. This study was supported in part through NIH/NCI Cancer Center Support grant P30CA008748.

Open Access This article is licensed under a Creative Commons Attribution 4.0 International License, which permits use, sharing, adaptation, distribution and reproduction in any medium or format, as long as you give appropriate credit to the original author(s) and the source, provide a link to the Creative Commons licence, and indicate if changes were made. The images or other third party material in this article are included in the article's Creative Commons licence, unless indicated otherwise in a credit line to the material. If material is not included in the article's Creative Commons licence and your intended use is not permitted by statutory regulation or exceeds the permitted use, you will need to obtain permission directly from the copyright holder. To view a copy of this licence, visit http://creativecommons.org/licenses/by/4.0/.

\section{References}

1. Maciejowski J, de Lange T. Telomeres in cancer: tumour suppression and genome instability. Nat Rev Mol Cell Biol 2017; 18, 175-186.

2. Bell RJ, Rube HT, Kreig A, Mancini A, Fouse SD, Nagarajan RP, Choi S, Hong C, He D, Pekmezci M, Wiencke JK, Wrensch MR, Chang SM, Walsh KM, Myong S, Song JS, Costello JF. Cancer. The transcription factor GABP selectively binds and activates the mutant TERT promoter in cancer. Science 2015; 348, 1036-1039.

3. Peifer M, Hertwig F, Roels F, Dreidax D, Gartlgruber M, Menon R, Kramer A, Roncaioli JL, Sand F, Heuckmann JM, Ikram F, Schmidt R, Ackermann S, Engesser A, Kahlert Y, Vogel W, Altmuller J, Nurnberg P, Thierry-Mieg J, Thierry-Mieg D, Mariappan A, Heynck S, Mariotti E, Henrich KO, Gloeckner C, Bosco G, Leuschner I, Schweiger MR, Savelyeva L, Watkins SC, Shao C, Bell E, Hofer T, Achter V, Lang U, Theissen J, Volland R, Saadati M, Eggert A, de Wilde B, Berthold F, Peng Z, Zhao C, Shi L, Ortmann M, Buttner R, Perner S, Hero B, Schramm A, Schulte JH, Herrmann C, O'Sullivan RJ, Westermann F, Thomas RK, Fischer M. Telomerase activation by genomic rearrangements in high-risk neuroblastoma. Nature 2015; 526, 700-704.

4. Valentijn LJ, Koster J, Zwijnenburg DA, Hasselt NE, van Sluis P, Volckmann R, van Noesel MM, George RE, Tytgat GA, Molenaar JJ, Versteeg R. TERT rearrangements are frequent in neuroblastoma and identify aggressive tumors. Nat Genet 2015; 47, 1411-1414.

5. Zehir A, Benayed R, Shah RH, Syed A, Middha S, Kim HR, Srinivasan P, Gao J, Chakravarty D, Devlin SM, Hellmann MD, Barron DA,
Schram AM, Hameed M, Dogan S, Ross DS, Hechtman JF, DeLair DF, Yao J, Mandelker DL, Cheng DT, Chandramohan R, Mohanty AS, Ptashkin RN, Jayakumaran G, Prasad M, Syed MH, Rema AB, Liu ZY, Nafa K, Borsu L, Sadowska J, Casanova J, Bacares R, Kiecka IJ, Razumova A, Son JB, Stewart L, Baldi T, Mullaney KA, Al-Ahmadie H, Vakiani E, Abeshouse AA, Penson AV, Jonsson P, Camacho N, Chang MT, Won HH, Gross BE, Kundra R, Heins ZJ, Chen HW, Phillips S, Zhang H, Wang J, Ochoa A, Wills J, Eubank M, Thomas SB, Gardos SM, Reales DN, Galle J, Durany R, Cambria R, Abida W, Cercek A, Feldman DR, Gounder MM, Hakimi AA, Harding JJ, Iyer G, Janjigian YY, Jordan EJ, Kelly CM, Lowery MA, Morris LGT, Omuro AM, Raj N, Razavi P, Shoushtari AN, Shukla N, Soumerai TE, Varghese AM, Yaeger R, Coleman J, Bochner B, Riely GJ, Saltz LB, Scher HI, Sabbatini PJ, Robson ME, Klimstra DS, Taylor BS, Baselga J, Schultz N, Hyman DM, Arcila ME, Solit DB, Ladanyi M, Berger MF. Mutational landscape of metastatic cancer revealed from prospective clinical sequencing of 10,000 patients. Nat Med 2017; 23, 703-713.

6. Gupta S, Vanderbilt C, Lin YT, Benhamida JK, Jungbluth AA, Rana S, Momeni-Boroujeni A, Chang JC, McFarlane T, Salazar P, Mullaney K, Middha S, Zehir A, Gopalan A, Bale TA, Ganly I, Arcila ME, Benayed R, Berger MF, Ladanyi M, Dogan S. A pancancer study of somatic TERT promoter mutations and amplification in 30,773 tumors profiled by clinical genomic sequencing. J Mol Diagn 2020; 23:253.

7. Bilimoria KY, Shen WT, Elaraj D, Bentrem DJ, Winchester DJ, Kebebew E, Sturgeon C. Adrenocortical carcinoma in the United States: treatment utilization and prognostic factors. Cancer 2008; 113, 3130-3136.

8. Else T, Kim AC, Sabolch A, Raymond VM, Kandathil A, Caoili EM, Jolly S, Miller BS, Giordano TJ, Hammer GD. Adrenocortical carcinoma. Endocr Rev 2014; 35, 282-326.

9. Else T, Williams AR, Sabolch A, Jolly S, Miller BS, Hammer GD. Adjuvant therapies and patient and tumor characteristics associated with survival of adult patients with adrenocortical carcinoma. J Clin Endocrinol Metab 2014; 99, 455-461.

10. Fassnacht M, Johanssen S, Quinkler M, Bucsky P, Willenberg HS, Beuschlein F, Terzolo M, Mueller HH, Hahner S, Allolio B, German Adrenocortical Carcinoma Registry G, European Network for the Study of Adrenal T. Limited prognostic value of the 2004 International Union Against Cancer staging classification for adrenocortical carcinoma: proposal for a Revised TNM Classification. Cancer 2009; 115, 243-250.

11. Fassnacht M, Kroiss M, Allolio B. Update in adrenocortical carcinoma. J Clin Endocrinol Metab 2013; 98, 4551-4564.

12. Zheng S, Cherniack AD, Dewal N, Moffitt RA, Danilova L, Murray BA, Lerario AM, Else T, Knijnenburg TA, Ciriello G, Kim S, Assie G, Morozova O, Akbani R, Shih J, Hoadley KA, Choueiri TK, Waldmann J, Mete O, Robertson AG, Wu HT, Raphael BJ, Shao L, Meyerson M, Demeure MJ, Beuschlein F, Gill AJ, Sidhu SB, Almeida MQ, Fragoso M, Cope LM, Kebebew E, Habra MA, Whitsett TG, Bussey KJ, Rainey WE, Asa SL, Bertherat J, Fassnacht M, Wheeler DA, Cancer Genome Atlas Research N, Hammer GD, Giordano TJ, Verhaak RGW. Comprehensive Pan-Genomic Characterization of Adrenocortical Carcinoma. Cancer Cell 2016; 29, 723-736.

13. Assie G, Letouze E, Fassnacht M, Jouinot A, Luscap W, Barreau O, Omeiri H, Rodriguez S, Perlemoine K, Rene-Corail F, Elarouci N, Sbiera S, Kroiss M, Allolio B, Waldmann J, Quinkler M, Mannelli M, Mantero F, Papathomas T, De Krijger R, Tabarin A, Kerlan V, Baudin E, Tissier F, Dousset B, Groussin L, Amar L, Clauser E, Bertagna X, Ragazzon B, Beuschlein F, Libe R, de Reynies A, Bertherat J. Integrated genomic characterization of adrenocortical carcinoma. Nat Genet 2014; 46, 607-612.

14. Weiss LM. Comparative histologic study of 43 metastasizing and nonmetastasizing adrenocortical tumors. Am J Surg Pathol 1984; 8, 163-169. 
15. Aubert S, Wacrenier A, Leroy X, Devos P, Carnaille B, Proye C, Wemeau JL, Lecomte-Houcke M, Leteurtre E. Weiss system revisited: a clinicopathologic and immunohistochemical study of 49 adrenocortical tumors. Am J Surg Pathol 2002; 26, 1612-1619.

16. Bisceglia M, Ludovico O, Di Mattia A, Ben-Dor D, Sandbank J, Pasquinelli G, Lau SK, Weiss LM. Adrenocortical oncocytic tumors: report of 10 cases and review of the literature. Int J Surg Pathol 2004; 12, 231-243.

17. Lau SK, Weiss LM. The Weiss system for evaluating adrenocortical neoplasms: 25 years later. Hum Pathol 2009; 40, 757-768.

18. Wong DD, Spagnolo DV, Bisceglia M, Havlat M, McCallum D, Platten MA. Oncocytic adrenocortical neoplasms--a clinicopathologic study of 13 new cases emphasizing the importance of their recognition. Hum Pathol 2011; 42, 489-499.

19. Cheng DT, Mitchell TN, Zehir A, Shah RH, Benayed R, Syed A, Chandramohan R, Liu ZY, Won HH, Scott SN, Brannon AR, O'Reilly C, Sadowska J, Casanova J, Yannes A, Hechtman JF, Yao J, Song W, Ross DS, Oultache A, Dogan S, Borsu L, Hameed M, Nafa $\mathrm{K}$, Arcila ME, Ladanyi M, Berger MF. Memorial sloan ketteringintegrated mutation profiling of actionable cancer targets (MSKIMPACT): a hybridization capture-based next-generation sequencing clinical assay for solid tumor molecular oncology. J Mol Diagn 2015; 17, 251-264.

20. Hyman DM, Solit DB, Arcila ME, Cheng DT, Sabbatini P, Baselga J, Berger MF, Ladanyi M. Precision medicine at Memorial Sloan Kettering Cancer Center: clinical next-generation sequencing enabling next-generation targeted therapy trials. Drug Discov Today $2015 ; 20,1422-1428$.

21. Ross DS, Zehir A, Cheng DT, Benayed R, Nafa K, Hechtman JF, Janjigian YY, Weigelt B, Razavi P, Hyman DM, Baselga J, Berger MF, Ladanyi M, Arcila ME. Next-generation assessment of human epidermal growth factor receptor 2 (ERBB2) amplification status: clinical validation in the context of a hybrid capture-based, comprehensive solid tumor genomic profiling assay. J Mol Diagn 2017; 19 , 244-254.

22. Gupta S, Vanderbilt CM, Cotzia P, Arias-Stella JA, III, Chang JC, Zehir A, Benayed R, Nafa K, Razavi P, Hyman DM, Baselga J, Berger MF, Ladanyi M, Arcila ME, Ross DS. Next-generation sequencing-based assessment of JAK2, PD-L1, and PD-L2 copy number alterations at 9p24.1 in breast cancer: potential implications for clinical management. J Mol Diagn 2019; 21, 307-317.

23. Gupta S, Cheville JC, Jungbluth AA, Zhang Y, Zhang L, Chen YB, Tickoo SK, Fine SW, Gopalan A, Al-Ahmadie HA, Sirintrapun SJ, Blum KA, Lohse CM, Hakimi AA, Thompson RH, Leibovich BC, Berger MF, Arcila ME, Ross DS, Ladanyi M, Antonescu CR, Reuter VE. JAK2/PD-L1/PD-L2 (9p24.1) amplifications in renal cell carcinomas with sarcomatoid transformation: implications for clinical management. Mod Pathol 2019; 32: 1344.

24. Gao J, Aksoy BA, Dogrusoz U, Dresdner G, Gross B, Sumer SO, Sun Y, Jacobsen A, Sinha R, Larsson E, Cerami E, Sander C, Schultz N. Integrative analysis of complex cancer genomics and clinical profiles using the cBioPortal. Sci Signal 2013; 6, pl1.

25. Zheng S, Cherniack AD, Dewal N, Moffitt RA, Danilova L, Murray BA, Lerario AM, Else T, Knijnenburg TA, Ciriello G, Kim S, Assie G, Morozova O, Akbani R, Shih J, Hoadley KA, Choueiri TK, Waldmann J, Mete O, Robertson AG, Wu HT, Raphael BJ, Shao L, Meyerson M, Demeure MJ, Beuschlein F, Gill AJ, Sidhu SB, Almeida MQ, Fragoso M, Cope LM, Kebebew E, Habra MA, Whitsett TG, Bussey KJ, Rainey WE, Asa SL, Bertherat J, Fassnacht M, Wheeler DA, Cancer Genome Atlas Research N, Hammer GD, Giordano TJ, Verhaak RGW. Comprehensive pan-genomic characterization of adrenocortical carcinoma. Cancer Cell 2016; 30, 363.

26. Pinto EM, Chen X, Easton J, Finkelstein D, Liu Z, Pounds S, RodriguezGalindo C, Lund TC, Mardis ER, Wilson RK, Boggs K, Yergeau D, Cheng J, Mulder HL, Manne J, Jenkins J, Mastellaro MJ, Figueiredo BC, Dyer MA, Pappo A, Zhang J, Downing JR, Ribeiro RC, Zambetti
GP. Genomic landscape of paediatric adrenocortical tumours. Nat Commun 2015; 6, 6302 .

27. Juhlin CC, Goh G, Healy JM, Fonseca AL, Scholl UI, Stenman A, Kunstman JW, Brown TC, Overton JD, Mane SM, Nelson-Williams C, Backdahl M, Suttorp AC, Haase M, Choi M, Schlessinger J, Rimm DL, Hoog A, Prasad ML, Korah R, Larsson C, Lifton RP, Carling T. Whole-exome sequencing characterizes the landscape of somatic mutations and copy number alterations in adrenocortical carcinoma. J Clin Endocrinol Metab 2015; 100, E493-502.

28. Liu T, Brown TC, Juhlin CC, Andreasson A, Wang N, Backdahl M, Healy JM, Prasad ML, Korah R, Carling T, Xu D, Larsson C. The activating TERT promoter mutation C228T is recurrent in subsets of adrenal tumors. Endocr Relat Cancer 2014; 21, 427-434.

29. Gara SK, Lack J, Zhang L, Harris E, Cam M, Kebebew E. Metastatic adrenocortical carcinoma displays higher mutation rate and tumor heterogeneity than primary tumors. Nat Commun 2018; 9, 4172.

30. Svahn F, Paulsson JO, Stenman A, Fotouhi O, Mu N, Murtha TD, Korah R, Carling T, Backdahl M, Wang N, Juhlin CC, Larsson C. TERT promoter hypermethylation is associated with poor prognosis in adrenocortical carcinoma. Int J Mol Med 2018; 42, 1675-1683.

31. Borah S, Xi L, Zaug AJ, Powell NM, Dancik GM, Cohen SB, Costello JC, Theodorescu D, Cech TR. Cancer. TERT promoter mutations and telomerase reactivation in urothelial cancer. Science 2015; 347, 1006-1010.

32. Bell RJ, Rube HT, Xavier-Magalhaes A, Costa BM, Mancini A, Song JS, Costello JF. Understanding TERT promoter mutations: a common path to immortality. Mol Cancer Res 2016; 14, 315-323.

33. Min J, Shay JW. TERT promoter mutations enhance telomerase activation by long-range chromatin interactions. Cancer Discov 2016; 6, 1212-1214.

34. Castelo-Branco P, Choufani S, Mack S, Gallagher D, Zhang C, Lipman T, Zhukova N, Walker EJ, Martin D, Merino D, Wasserman JD, Elizabeth C, Alon N, Zhang L, Hovestadt V, Kool M, Jones DT, Zadeh G, Croul S, Hawkins C, Hitzler J, Wang JC, Baruchel S, Dirks PB, Malkin D, Pfister S, Taylor MD, Weksberg R, Tabori U. Methylation of the TERT promoter and risk stratification of childhood brain tumours: an integrative genomic and molecular study. Lancet Oncol 2013; 14, 534-542.

35. Papathomas TG, Pucci E, Giordano TJ, Lu H, Duregon E, Volante M, Papotti M, Lloyd RV, Tischler AS, van Nederveen FH, Nose V, Erickson L, Mete O, Asa SL, Turchini J, Gill AJ, Matias-Guiu X, Skordilis K, Stephenson TJ, Tissier F, Feelders RA, Smid M, Nigg A, Korpershoek E, van der Spek PJ, Dinjens WN, Stubbs AP, de Krijger RR. An International Ki67 Reproducibility Study in adrenal cortical carcinoma. Am J Surg Pathol 2016; 40, 569-576.

36. Duregon E, Molinaro L, Volante M, Ventura L, Righi L, Bolla S, Terzolo M, Sapino A, Papotti MG. Comparative diagnostic and prognostic performances of the hematoxylin-eosin and phosphohistone $\mathrm{H} 3$ mitotic count and Ki-67 index in adrenocortical carcinoma. Mod Pathol 2014; 27, 1246-1254.

37. Giordano TJ. The argument for mitotic rate-based grading for the prognostication of adrenocortical carcinoma. Am J Surg Pathol 2011; 35, 471-473.

38. Mouat IC, Giordano TJ. Assessing biological aggression in adrenocortical neoplasia. Surg Pathol Clin 2014; 7, 533-541.

39. Beuschlein F, Weigel J, Saeger W, Kroiss M, Wild V, Daffara F, Libe R, Ardito A, Al Ghuzlan A, Quinkler M, Osswald A, Ronchi CL, de Krijger R, Feelders RA, Waldmann J, Willenberg HS, Deutschbein T, Stell A, Reincke M, Papotti M, Baudin E, Tissier F, Haak HR, Loli P, Terzolo M, Allolio B, Muller HH, Fassnacht M. Major prognostic role of Ki67 in localized adrenocortical carcinoma after complete resection. J Clin Endocrinol Metab 2015; 100, 841-849.

40. Libe R, Borget I, Ronchi CL, Zaggia B, Kroiss M, Kerkhofs T, Bertherat J, Volante M, Quinkler M, Chabre O, Bala M, Tabarin 
A, Beuschlein F, Vezzosi D, Deutschbein T, Borson-Chazot F, Hermsen I, Stell A, Fottner C, Leboulleux S, Hahner S, Mannelli M, Berruti A, Haak H, Terzolo M, Fassnacht M, Baudin E, network E. Prognostic factors in stage III-IV adrenocortical carcinomas (ACC): an European Network for the Study of Adrenal Tumor (ENSAT) study. Ann Oncol 2015; 26, 2119-2125.
Publisher's Note Springer Nature remains neutral with regard to jurisdictional claims in published maps and institutional affiliations. 